\title{
Case study analysis for the successful completion and sustainable construction of infrastructure projects
}

\author{
I. Othman, M. Napiah \& N. S. Potty \\ UniversitiTeknologi PETRONAS, Malaysia
}

\begin{abstract}
Case studies of infrastructure projects are carried out using qualitative analysis methods and findings on the factors causing successful completion and sustainable construction are presented. There are three distinct ways to do this namely (1) management at pre-design stage, (2) management during the construction phase and (3) by interviewing experts. The element optimization technique has been applied to the project under the management at pre-design stage. The analysis revealed that the critical component is traffic diversion management which has a greater than $17 \%$ presence. The construction of the bridge over Kinta River and environmental protection works have both nearly $17 \%$ presence for project 1 . For project 2, the analysis revealed that critical components are environmental protection works and earthworks which have greater than $18 \%$ presence. This research study suggests the adoption of few design optimizations and to reduce the complexity and ease of their implementation in the field. The analysis for management during the construction phase has arrived at the findings that activities of the project are behind time due to improper planning in carrying out works such as spreading, grading and compacting suitable material to form embankments, importing suitable fill as surcharge, piling for embankment, box culverts, the bridge over Kinta River, the bridge over Lereh River and the pavement. The top three riskiest factors for obstructing successful completion and sustainable construction from the point of view of experts, inclusive of client, consultant and contractor are "mis-management of the project by the three parties namely contractor, consultant and owner leading to unsuccessful completion and unsustainable construction", "shortage and lack of quality materials and
\end{abstract}


appropriate equipment in the local market" and "lack of material delivery schedule prepared by the contractor".

Keywords: successful completion, sustainable construction, component optimisation, construction progress reports, qualitative analysis.

\section{Introduction}

Risk identification and assessment are the primary aims of qualitative risk analysis for successful completion and sustainable construction. The objective of qualitative risk analysis is to compile the main risk sources and a description of their likely consequences [1]. Common techniques for qualitative risk analysis includes the use of risk checklists compiled from previous projects, interviewing key project participants, project case study and project team brain storming workshops [2]. Interviews and project case study were adopted as an appropriate method for collecting the qualitative data required for this research.

The project 1 consists of construction of 8.2 kilometres road with 7 meters width and 2.5 meter shoulders inclusive of 1.5 meters pavement shoulder. The project implementation activity started on $20^{\text {th }}$ April 2009 and was to complete by April 2011. The project was delayed due to EOT by 5 months until September 2011. The project 2 consists of upgrading works of 8.9 kilometres road with 7 meters width and 2.5 meter shoulders. The project implementation activity started on $19^{\text {th }}$ December 2009 and was to be completed by August 2011. The project was delayed for 4 months with 2 EOTs until December 2011. Project 3 has construction period from June 2010 to June 2012. Towards the end of the projects, there were a number of meetings and memos were given by the consultant to the contractor for making work mitigation plans to catch-up the work progress.

The project case studies were conducted in Perak in West Malaysia with plenty of natural resources such as stones, aggregates, river sand, cement, etc. However, considering the development works in the state the locally available quality raw materials are negligible to meet the requirements by the construction industry. In spite of these large drawbacks the industry needs to progress well to meet the development plans and implement the projects successfully.

\section{Project case study}

The case studies taken up for this research are infrastructure projects. The owner of the project is the Public Works Department of Perak funded by the Ministry of Works, Malaysia. These are federal development projects and the main objective of the projects is for the Perak state to provide proper infrastructure for social and economic development of that region.

\subsection{Project life cycle}

The project life cycle starts from the day of project conception until project completion and handover after defect liability period [3]. Contractually, 
consultant and client need to work together from field investigation, observation, topographic survey, soil investigation to start the feasibility study facilitating the development of conceptual design for the project.

\subsection{Causes of successful completion and sustainable construction through project case study}

The projects are studied to identify the successful completion and sustainable construction factors for verification with the factors identified in quantitative analysis. The research work identifies the causes of successful completion and sustainable construction factors experienced in practical field. This research has been divided into three sections which are: management at pre-design stage, management during construction phase and interview experts as shown in Figure 1.

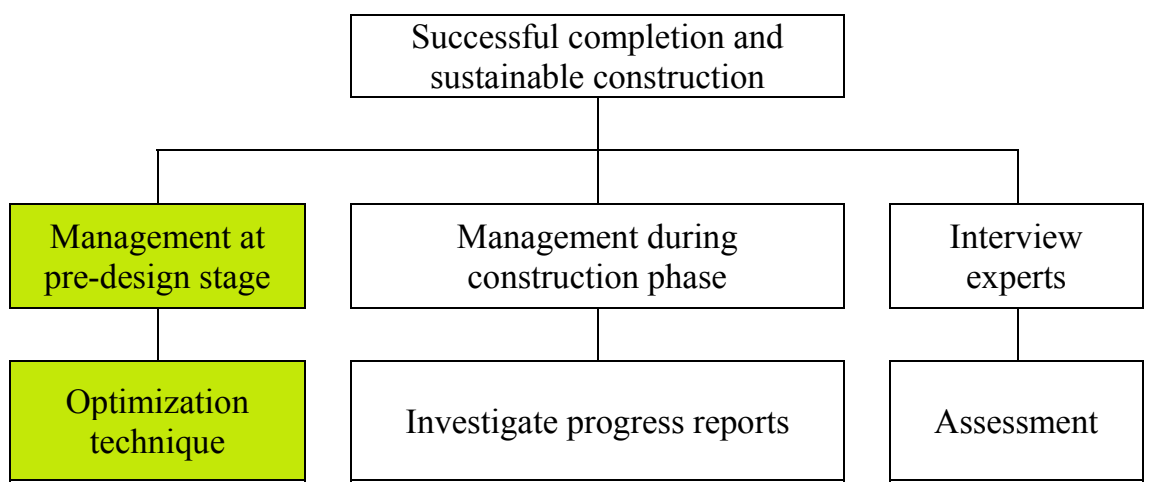

Figure 1: Flowchart of methods used in a case study to study successful completion and sustainable construction problems.

\section{Result and discussion}

The lack of knowledge of design professionals to consider how a builder will implement the design can result in scheduling problems, delays and complicated disputes during the construction. Hence the design stage plays an important role. This proactive approach at early stages of design phases will eliminate the complex problem and help to complete the project on time.

\subsection{Management at pre-design stage}

The construction process and success in the management of infrastructure projects directly relies on the selection and optimization of their components at pre design stage [4]. A systematic optimization process is needed to be adopted during the conceptual design stage to overcome the resource constraints during the construction phase [5]. The knowledge of construction experience is also 
utilized during the element optimization process as presented in the following sections of projects.

\subsection{Element optimisation technique}

Infrastructure projects are normally designed with high quality and safety standards with stringent execution works and inspections. Construction problems encountered during execution are complex and costly. Many construction problems can be avoided with proper attention and consideration of the construction process during the design phase [6]. Factors of simplicity, flexibility, sequencing, substitutions and labour skill and its availability should be a part of design. The appropriate use of standardization can have several benefits. These include increased productivity and quality from repetitive field operations, reduction in design time, savings from volume discounts in purchasing, and simplified materials management. This method of standardizing components may be suitable for selective projects of same nature but are less significant and more complex for infrastructure projects situated at different geographical locations and conditions [7]. The element ratio is the percentage contribution of each component of the project. Each component may have different percentage based on their weights or importance in the project. The weights were computed using a common and consistent factor. In this case study the duration parameter is used to calculate the element weights.

\subsubsection{Item component ratio for project 1}

The details and components in project 1 are summarized in Table 1. The individual component ratio is derived and is shown in Table 1. From the duration weights breakdown it is clear that the critical component is traffic diversion management which has greater than $17 \%$ presence. Bridge over Kinta River and environmental protection works have both approximately $17 \%$ presence. The influence of traffic diversion management is very high due to the fact that the traffic management team needs to be at project site from the start of construction until the completion of project to ensure the safety of project team members and public. Also, temporary road signs are required to be installed for the whole duration of construction to avoid accidents at project site. Bridge over Kinta River also has quite high component ratio of about $16.64 \%$ because there are many sub-components involved to complete the bridge construction such as excavation for pile cap and abutment, temporary bridge and coffer dam, supply and deliver $700 \mathrm{~mm}$ spun piles, handle, pitch and drive $700 \mathrm{~mm}$ spun piles, cut off piles, carry out initial and subsequent maintained load test and carry out pile driving analyser test. Furthermore, construction of bridge comprises of 9 piers which involve formwork, rebar, concreting, dry sand backfill and bituminous coating. Also, other works like abutment, deck, diaphragm beam, pipe support, parapet wall, joints, bearings and railings are necessary to complete the construction works of the bridge.

The component environmental protection work has weight of $16.62 \%$ which is third highest for project 1 . This is due to the many sub-components under environmental protection works such as dust control, wash through facilities, 
erosion control, silt trap and environmental monitoring which are required to be carried out from the beginning of the construction until completion of the projects.

Table 1: $\quad$ Average duration weights of component in percentage for project 1.

\begin{tabular}{|l|l|c|c|}
\hline No. & Description & Duration (day) & Ratio (\%) \\
\hline 1 & Site clearance & 305 & 6.77 \\
2 & Earthworks & 370 & 8.21 \\
3 & Geotechnical works & 572 & 12.69 \\
4 & Drainage & 416 & 9.23 \\
5 & Traffic diversion/management & 790 & 17.53 \\
6 & Environmental protection works & 749 & 16.62 \\
7 & Bridge over Kinta River & 750 & 16.64 \\
8 & Bridge over Air Lereh River & 262 & 5.81 \\
9 & Flexible pavement & 280 & 6.21 \\
10 & Roadside furniture & 12 & 0.26 \\
\hline & TOTAL & 4506 & $100.00 \%$ \\
\hline
\end{tabular}

\subsubsection{Item component ratio for project 2}

The individual component ratio for project 2 is derived and is shown in Table 2. The most critical components are earthworks and environmental protection works which have approximately $18 \%$ weight. Drainage works has about $17 \%$ weight. Earthworks which include stripping of topsoil, cuttings, fillings, turf and hydro-seeding together with environmental protection works have the highest weight of $18.01 \%$. This is because 8.9 kilometres length of the road requires earthworks before roadbase and pavement can be laid along the stretch. Also environmental protection works are required from the start until completion of road construction to ensure that pollution and disturbance to surrounding are minimized. Drainage works which comprise of temporary works, new and extension of pipe culvert, box culvert, surface drains and sumps have the third

Table 2: $\quad$ Average duration weights of component in percentage for project 2.

\begin{tabular}{|l|l|c|c|}
\hline No. & Description & Duration (day) & Ratio (\%) \\
\hline 1 & Site clearance & 162 & 4.86 \\
2 & Earthworks & 600 & 18.01 \\
3 & Geotechnical works & 567 & 17.02 \\
4 & Drainage works & 576 & 17.29 \\
5 & Traffic diversion/management & 500 & 15.01 \\
6 & Environmental protection works & 600 & 18.01 \\
7 & Flexible pavement & 298 & 8.94 \\
8 & Roadside furniture & 28 & 0.84 \\
\hline & TOTAL & 3331 & $100.00 \%$ \\
\hline
\end{tabular}


highest weight with $17.29 \%$. This is because of the 8.9 kilometres of the road which require drainage works to ensure that flooding is avoided in the areas surrounding the project.

Based on the above analysis, it is easier to make the appropriate component during the conceptual design phase. This decision at pre-design stage will eliminate considerable number of risk factors that may cause problems and lead to unsuccessful project completion. This research work has proven that qualitative analysis is very important for projects. Therefore, the uniform distribution of component ratio will facilitate the contractor to execute the physical works simultaneously with proper planning in place.

\subsection{Management during the construction phase}

Management during construction is the second phase and consists of investigation of progress reports as shown in Figure 2.

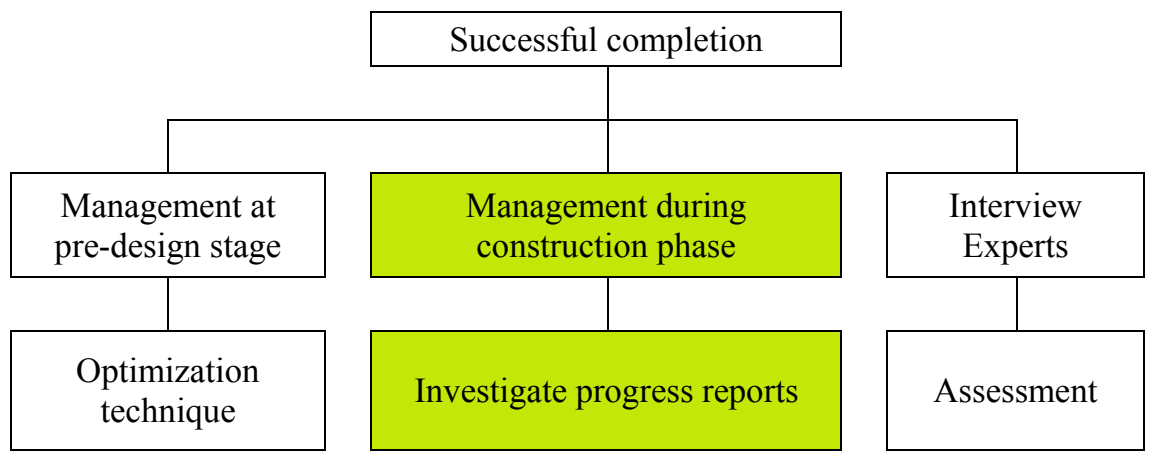

Figure 2: $\quad$ Flowchart of methods used in a case study to study successful completion and sustainable construction problems.

\subsection{Investigate progress reports}

This section describes the distinct approach of studying projects, which is investigation of project performance by analysing the progress report to identify the factors that contribute to successful completion. It is important to understand the roles of participants and their activities in infrastructure projects, by which it is possible to assign the responsibility for the successful completion factors identified in this study. The construction periods of the projects were mapped for better understanding of the projects. The investigation, feasibility studies, conceptual design, discussion and approval phases of projects occur before the construction phase of each project.

The construction of project 1 is divided into eight major activities for completion. The key activities for the completion of project 1 are site clearance, earthworks, geotechnical works, drainage, traffic diversion/management, environmental protection works, and bridge over Kinta River and flexible pavement. The number of days actually taken for completing these key activities 
is calculated from the scheduled start date, actual start date, scheduled finish date and actual finished date to indicate the slack from the finish date of one activity to the start date of the next activity. This period is the actual delay or unsuccessful completion at site. The practical problem behind this delay/slack is discussed for identifying the factors causing unsuccessful completion. The factors identified are based on practical happenings at the site. The duration of key activity completion is taken from finish date of a predecessor activity to start date of a successor activity. Two aspects of the results are discussed namely (1) problems of work activity and (2) the factor causing delay to the start the successor activity.

The actual construction period of each and every activity of the project 2 are recorded. The construction of this project is divided into eight major stages for completion. The key stages in the construction are site clearance, earthworks, geotechnical works, drainage, traffic diversion/management, environmental protection works, flexible pavement and roadside. The number of days actually taken for completing these key stages is calculated from the list of request for inspection to indicate the slack from the finish date of one stage to the start date of the next stage. The practical problem causing this slack is identified for deriving the factors causing the unsuccessful completion. The factors identified are based on investigations of the site conditions and thus have immense practical value. Request for inspection is used to calculate the duration of key stage and the duration taken from finish date of a predecessor activity to start date of a successor activity.

\subsubsection{Analysis of progress of work in project 1}

Investigation on the progress of work in project 1 showed that earthworks which consist of spread, grade and compact suitable material to form embankment from chainage $0-4000$ caused delay to the project by $6 \%$. Pile embankment which consists of handle, pitch, drive, cut-off and load test under geotechnical works was also behind schedule by $34 \%$. Construction of $3.7 \mathrm{~m} \times 3 \mathrm{~m}$ box culvert inclusive of excavation, formwork, reinforcement and concreting under drainage works was delayed by $80 \%$ due to delay in approval from client. However construction of a triple box culvert which includes supply and installation under drainage works was ahead by $25 \%$. Embankment toe drain and in-situ drain were delayed by $40 \%$ while culvert headwall was also delayed by $25 \%$. Traffic diversion works which consists of traffic management team, temporary road furniture and temporary signs progressed as scheduled. Also environmental protection works such as preparation of environmental protection plan, dust control, wash through facilities, erosion control, silt trap, skid tank and environmental monitoring progressed according to schedule. Excavation for pile cap and abutment works for bridge over Kinta River were ahead by $47 \%$. Temporary bridge and coffer dam were also ahead by $21 \%$. Piling works for bridge over Kinta River inclusive of supply of $700 \mathrm{~mm}$ spun piles, handle, pitch, drive, cut off piles and load test were ahead by $13 \%$. However, construction of abutment A, wing wall, approach slab consist of rebar, formwork, concreting work, bitumen coating, granular backfill progressed as per schedule. Also 
formwork, rebar, concreting works and dry sand backfill for piers 1, 2, 3 and bridge over Kinta River progressed as scheduled. Meanwhile, formwork, rebar, concreting and bituminous coating works for piers 4, 5, 7, 8 and 9 were behind time by $100 \%$ due to change of design requested by client. Rebar, formwork, concreting, bitumen coating and granular backfill for Abutment B are behind time by $100 \%$ due to change of design by the client. Works for deck inclusive of formwork, rebar and concrete grade 40 were behind time by $14 \%$, Casting and launching for diaphragm beam were also behind time by $14 \%$. Piling $375 \mathrm{~mm} x$ $375 \mathrm{~mm}$ reinforced concrete piles inclusive of supply of piles, mobilisation piling frame, handle, pitch, drive, cut off piles, maintained load test and pile driving analyser test for bridge over Lereh River were behind time by $19 \%$.

Abutment/wingwall/approach slab which consists of formwork, rebar, concrete grade 40 and coating works were also behind time by $65 \%$. Formwork, rebar, concrete grade 40 for deck and diaphragm beam were $45 \%$ behind time. However supply and erection of beams were $3 \%$ ahead of time, while supply and fit pre-stressing cable for diaphragm beam were 55\% ahead time. Preparation of formation for flexible pavement from chainage 0 to chainage 2000 was behind time by $25 \%$. Also preparation of formation for flexible pavement from chainage 2000 to chainage 4000 was behind time by $16 \%$. Supply, grade and compact subbase for chainage 0 to chainage 2000 was $25 \%$ behind time. However supply, grade and compact subbase for chainage 2000 to chainage 4000 were ahead time by $25 \%$. Meanwhile, supply, grade and compact road base for chainage 0 to chainage 2000 were $3 \%$ behind time. This delay involves additional cost to the contractor because there was no compensation for this from any authority. The contractor still faces cost overrun due to extension of time which has increased their project overheads and operational cost.

\subsubsection{Analysis of progress of work in project 2}

Investigation on the physical progress of activities in project 2 showed that cutting earthworks for chainage 4900 - chainage 5100 and chainage $6330-$ chainage 6525 (LHS) were $10 \%$ behind time. While cutting earthworks for chainage 350 - chainage 700 and chainage 6330 - chainage 6525 (RHS) are 1\% and $2 \%$ behind time respectively. However cutting earthworks for chainage 8500 -chainage 8875 were $20 \%$ behind time. Cutting earthworks for chainage 4600 -chainage 4800 were $5 \%$ behind time and $17 \%$ behind time for chainage 4225-chainage 4425. Filling earthworks for chainage 0 -chainage 1000 were $4 \%$ behind time. However for chainage 2000-3000, earthworks filling were $30 \%$ behind time. For chainage $3000-4000$, 5\% behind time were recorded for earthworks filling. Progress for earthworks filling was $40 \%$ behind time for chainage 4000-5000. Filling earthworks for chainage 5000-6000 were 10\% behind time and $26 \%$ behind time for chainage 6000-7000. There were $4 \%$ behind time filling earthworks for chainage 7000-8000. Earthworks filling were $5 \%$ behind time for chainage $8000-8875$. For turf and hydro seeding works, $51 \%$ behind time were recorded. Temporary works for drainage inclusive of mobilisation and demobilisation were $10 \%$ behind time. 
Construction of pipe culvert was $26 \%$ behind time, while construction of box culvert was $34 \%$ behind time. Construction of surface drain and sump were $28 \%$ behind time. Preparation of formation and sub base for pavement works were $60 \%$ behind time, while road base was $68 \%$ behind time. Prime coat and asphaltic concrete binder course (ACB) were $40 \%$ behind time. Tack coat and asphaltic concrete wearing course (ACW) were $70 \%$ behind time. Earth shoulder was $38 \%$ behind time. Treatment to existing pavement was $20 \%$ behind time. Soft ground improvement works were $8 \%$ behind time. Slope stabilisation and retaining works were $71 \%$ behind time. Environment protection control works were $6 \%$ behind time. Routine maintenance works were $48 \%$ behind time. As a whole the work was progressing ahead of the scheduled work progress.

\subsection{Interview with experts}

The experts interviewed are chosen from the contracting parties of the infrastructure projects. These experts were interviewed in their own offices with prior appointments. The intention was to maintain the flow of dialogue but to help channel conversation in a manner most beneficial to harvesting appropriate data. The questions were generalized and focused more on factors affecting successful completion and sustainable construction. Individual characteristics of each project are briefed in the following section.

The three parties to the project comprising of the contractor, the consultant and the owner were interviewed, each evaluating the case through their point of view. The research findings from the above projects are presented according to scientific study, opinion and lessons learned.

\subsection{Assessment}

The assessment was based on the case studies. The challenging factors for the successful completion were obtained by interviewing each of the parties to the contract. Their opinions are summarized as follows:

\subsubsection{Contractors' opinion}

The challenging factors for successful completion in the opinion of the contractors are as follows:

1. Delay in payment by client for progress of work done.

2. Delay to approve material by consultant.

3. Delay in obtaining permits by consultant from relevant authorities.

4. Change order by client.

5. Late approval of drawings by relevant authorities.

6. Poor communication between consultant and client in getting approval for change order.

7. Slow decision by client on approval of progress payment.

8. Suspension of work by client due to miscommunication with consultant.

9. Delay to perform inspection by consultant.

10. Inflexibility of working hours amongst consultant to perform inspection.

11. Conflict between designers in consultant office. 
12. Inadequate experience amongst consultant's staff.

13. Change in specification by consultant.

14. Shortage of materials supplied by the supplier.

15. Delay in delivery of materials by supplier.

16. Damage of material delivered to site by supplier.

17. Delay in manufacturing of precast units by supplier.

18. Late selection of materials by client.

19. Unclear drawing details by consultant.

20. Complexity of design by consultant.

\subsubsection{Consultants' opinion}

The consultant reported the following most important challenging factors to successful completion:

1. Difficulty in financing the construction project by contractor.

2. Incomplete sub-contract schedule by contractor with sub-contractor.

3. Rework due to errors by contractor.

4. Poor site management by contractor.

5. Ineffective construction planning by contractor.

6. Improper construction methods by contractor.

7. Poor qualification of contractor's staffs.

8. Delay in site mobilization by contractor.

9. Inadequate experience of staffs in contractor's site office.

10. Poor communication between contractor's site office and main office.

11. Inadequate materials delivered on site.

12. Machine breakdown by contractor's workers.

13. Shortage of necessary equipment on site.

14. Low level skill and competency of operators to handle equipment.

15. Inefficient machines and equipments used by contractors.

16. Lack of high technical equipment on site.

17. Design data is not available at the right time causing changes to the design at the time of construction.

18. The dependency on specialist works without alternative plans.

19. Limited working hours by contractor.

20. The land and property acquisition obstructing construction work.

\subsubsection{Clients' opinion}

The owners' report on successful completion are summarized as follows:

1. Too short contract duration provided by consultant in contract document.

2. Legal disputes between contractor and consultant.

3. Inadequate definition and unclear scope of work to be carry out by contractor.

4. Ineffective delay penalties provided by consultant in contract document.

5. Incomplete contract document for construction prepared by consultant.

6. Delay of project bidding handled by consultant.

7. Mismanagement by the contractor and the consultant to complete and deliver project on time.

8. Mistakes and discrepancies of drawings prepared by consultant. 
9. Delay in producing detailed drawings by consultant.

10. Unclear detailed drawings prepared by consultant.

11. Complexity of design by consultant.

12. Insufficient design data supplied to consultant by supplier.

13. Inadequate design team in consultant office.

14. Insufficient design period in consultant office.

15. Unforeseen original site condition by consultant.

16. Slow delivery of material by contractor to the site. No proper material delivery schedule is in place.

17. Inappropriate construction method by contractors.

18. Less quality and reworks by contractor due to work speeding.

19. Price variation of the construction materials and fossil fuels.

20. Bad weather conditions.

\section{Conclusions}

Interviews with project team (client, consultant, and contractor) were carried out to obtain clarification on the most critical factors for successful completion. In Client's opinion the factors were the slow delivery of material by contractor to the site due to no proper material delivery planning schedule, and mismanagement by the contractor and the consultant to complete and deliver project on time due to failure of both parties to monitor performance and feedback. Client also highlights that inappropriate construction methods used by contractors due to their incompetent project team.

Consultant mentions that contractors do not have complete planning schedule for all construction activities and only depend on sub-contractor specialist work schedule. Consultant points out other factors kike the lack of materials at site and the failure of the contractor to monitor performance and feedback from subcontractor works. Poor judgment in estimating time and resources by contractor due to incompetent project team of contractor also contributed.

From a contractor's point of view, the lack of progress of specialist works occurred due to inefficient planning by their sub-contractor. Also contractor mentions the delay in the approval of materials and failure of consultant to monitor performance and feedback from contractor. Contractor's also highlight the continuous changes in design and drawing which occur due to incompetent consultant's project team and as a result obstruct the smooth progress towards successful completion.

\section{References}

[1] Hull, J.K., "Application of Risk Analysis Techniques in Proposal Assessment", International Journal of Project Management, Vol. 8, No. 3, pp. 153-157, 1990.

[2] Bowers, J.A., "Data for Project Risk Analysis", International Journal of Project Management, Vol. 12, No. 1, pp. 9-16, 1994. 
[3] PMI, "A Guide to Project Management Body of Knowledge", 3rd Edition, Project Management Institute, USA, 2004.

[4] Abdul-Rahman, H, Berawi, A.R., Othman, M., "Delay Mitigation in the Malaysian Construction Industry", Journal of Construction Engineering and Management ASCE, Vol. 132, No. 2, pp. 125-133, 2006.

[5] I. Othman, A. Idrus \& M. Napiah, "Human Resource Management in the Construction of a Sustainable Project: Towards Successful Completion" WIT Transactions on Ecology and The Environment, Vol. 162, C2012 WIT Press, www.witpress.com

[6] Al-Bahar, J.F., Crandall, K.C. "Risk Management in Construction Projects: A Systematic Approach for Contractors", CIB 90 Conference, Sydney, 1990.

[7] Rashid, Z.Z.A., Adnan, H., Malaysian Legal Framework and Risk Management: Design Professionals", Sixth International Conference in the 21st Century, Kuala Lumpur, pp. 685-692, 2011. 